\title{
Irrigation management to improve smallholder's incomes for saline conditions
}

\author{
Fathia El Mokh ${ }^{1 *}$, Kamel Nagaz ${ }^{1}$, Mohamed Moncef Masmoudi ${ }^{2}$, Netij Ben Mechlia ${ }^{2}$ \\ ${ }^{1}$ Institut des Régions Arides, 4119 Médenine, Tunisia \\ ${ }^{2}$ INAT, 2083 Tunis, Tunisia
}

\begin{abstract}
In the Mediterranean arid regions, the water limitation is the constraint major for agriculture development. Under this condition, one of the most common water quality concerns for irrigated agriculture is saline. The use of this saline water is increasing with the increasing of water scarcity. Its use without integrate management (soil, crop and water) poses high risks of land degradation and crop productivity reduces. Therefore, this study was considered in southern Tunisia to investigate farmer irrigation practices over two years. The impact of irrigation strategies with saline water $(6 \mathrm{dS} / \mathrm{m})$ on yield, soil salinity, water productivity and farmer net return were evaluated. Five crops were considered: barley, carrot, fava bean, pepper and potato. The irrigation strategies based on soil water balance method (SWB) which are full irrigation strategy (FI: restore $100 \%$ of the crop evapotranspiration) and deficit treatment (DI70: $70 \%$ of the ETc covered) were compared to farmer practice (FM). For both seasons, FM strategy caused a significant increase in soil salinity that affects considerably the yield produced for most of the crops compared to the full and the deficit (30\%) water supply strategies. The water restriction of 30\% improves the total water productivity without affecting yield significantly especially for barley and faba bean where the yield reduction was ranging from 2.5 to $9.5 \%$. Results showed that the practice of cash crops (potato, carrot and faba bean) which have a short cycle improves considerably the farmer incomes compared to the barley crop. The pepper provides also high economic return for farmer but it consumes more water and has a long growing cycle. Based on this analysis, the farmer income can be improved considerably with better irrigation and crop management.
\end{abstract}

Key words: Water management, Salinity, Yield, Water productivity, Farmer return.

\section{INTRODUCTION}

In arid regions of Tunisia, the development of irrigation has been increased around shallow wells having high salinity levels. Local practices give to vegetable and cereal crops an important place in small-scale irrigation schemes, however, crop productivity remains low (El Mokh el al., 2011). In addition, the intensive use of saline water without provision drainage system is increasing the risk of rapid soil salinization and in many cases renders it unsuitable for cultivation. Due to the high cost of installation the smallholders in the regions are unable to introduce drainage system and high cost irrigation management technologies.

To overcome the effects of water shortage in small scale agriculture, improve farmer incomes and food insecurity, and avoid the negative impacts of climate change, the introduction of low cost water-saving irrigat ${ }^{*}$ ion technologies have been identified as key and realistic components of reducing agricultural water demand in many similar regions in the world (Horst et al., 2005, Webber, 2008 and Erkossa et al., ). Thus, the solutions in our case should lie on the improvement of agricultural practices through the use of simple and efficient means.

To this end, there is a necessity to study and evaluate the farmer's practices in order to improve their practices and ensure the crop systems sustainability. To attend these objectives, there is a critical need to increase irrigation efficiency through the use of more efficient methods and the development of new irrigation scheduling techniques such as full irrigation and deficit irrigation, which is not necessarily based on full crop water requirement. In the same way, the choice of the suitable crops could be an interesting

\footnotetext{
* Corresponding author e-mail: elmokh.fa@gmail.com
} 
alternative to better valorize the unfavorable climate and water conditions and to insure durable revenue for farmers. This evaluation was conducted with farmer's participation in order to improve their knowledge about the crop water requirements and to identify the crop systems adapted to the changeable conditions.

\section{MATERIALS AND METHODS}

\subsection{Experimental site}

Field experiments were conducted in a commercial farm situated in Bedoui in the region of Medenine, Southern Tunisia $\left(33^{\circ} 27^{\prime} \mathrm{N}, 10^{\circ} 31^{\prime} \mathrm{E}\right.$; altitude $\left.55 \mathrm{~m}\right)$. The climate is typical of arid areas. The mean monthly rainfall data and that registered during the study period (2012-2015) are presented in figure 1. No rainfall was received in the first year 2012/2013, while 145 and $80 \mathrm{~mm}$ were received in 2013-2014 and 2014-2015, respectively, during the cropping periods. The cultivated crops were barley, carrot, pepper, faba bean and potato, each crop has benefited of rainfall events according to its cropping period.

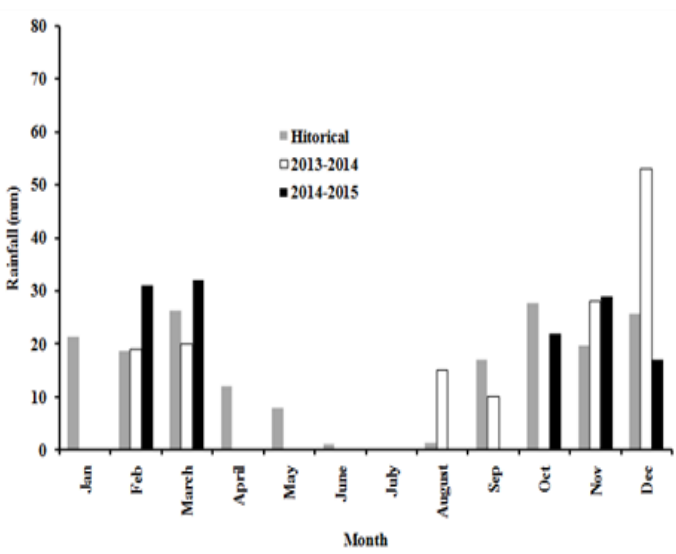

Figure 1. Historical average monthly rainfall data and that for the study period (20132015).

The soil of the experimental site is sandy with $80.6 \%$ sand, $12.6 \%$ silt and $6.8 \%$ clay. Average mass basis water content values in the $100 \mathrm{~cm}$ topsoil for field capacity and permanent wilting point are, respectively, 0.115 and $0.067 \mathrm{~g} / \mathrm{g}$ and organic matter content is $7.7 \mathrm{~g} / \mathrm{kg}$. The bulk density of soil was $1.57 \mathrm{~g} / \mathrm{cm}^{3}$ as shown in table 2 . The total soil available water calculated between field capacity and wilting point for an assumed root extracting depth of $1.00 \mathrm{~m}$, was $74 \mathrm{~mm}$.

\subsection{Crop management and experimental design}

Fertilizers were supplied for all field experiments according to fertilizer levels used by farmers for vegetable and barley crops in the region of Medenine, Tunisia. Before planting of potato, carrot, fava bean and pepper crops, respectively, 17, 1.7-2.5, 5.2-6.9 and $25 \mathrm{t} / \mathrm{ha}$ of organic manure were applied to the soil.

Inorganic nutrient supply consisting of giving Nitrogen $(\mathrm{N}), \mathrm{P}_{2} \mathrm{O}_{5}$ and $\mathrm{K}_{2} \mathrm{O}$, respectively, at rates of 279-297, 148 and 0 $\mathrm{kg} / \mathrm{ha}$ for barely; 300, 200 and $200 \mathrm{~kg} / \mathrm{ha}$ for potato; 200-300, 0 and $80-104 \mathrm{~kg} / \mathrm{ha}$ for carrot; 200-300, 300 and $0-270 \mathrm{~kg} / \mathrm{ha}$ for fava beans and 150, 100 and $0 \mathrm{~kg} / \mathrm{ha}$ for Pepper. The $\mathrm{P}_{2} \mathrm{O}_{5}$ and $\mathrm{K}_{2} \mathrm{O}$ fertilizers were applied as a basal dose before planting. Nitrogen was divided and delivered with the irrigation water in all treatments during early vegetative growth. For potato, $120 \mathrm{~kg} / \mathrm{ha}$ of potassium nitrate was applied after the tuber initiation stage.

A randomized complete block design was adopted with three replicates for each experiment. Each plot included a specified number of rows depending to the crop and farmer needs. All plots were drip-irrigated using well waters having an electrical conductivity (ECiw) of $6 \mathrm{dS} / \mathrm{m}$. Each row was equipped with a dripline including emitter spaced $40 \mathrm{~cm}$. The dripper flow rate was $4 \mathrm{l} / \mathrm{h}$. Before each experimental field, water meter and gate valves were placed in addition of mini-valve for each row to control water supply. Two treatments used soil water balance (SWB) and consist in delivering total or a fraction of cumulated ETc when readily available water in the root zone, which represents $40 \%$ of total available water, was depleted. The amount of water applied for the SWB method was 
Table 1. Physical and chemical characteristics for the study site in Medenine

\begin{tabular}{|c|c|c|c|c|c|c|c|}
\hline \multirow{2}{*}{$\begin{array}{l}\text { Soil layer } \\
(\mathrm{cm})\end{array}$} & \multicolumn{3}{|c|}{ Particles (\%) } & \multirow{2}{*}{$\begin{array}{l}\text { Organic manure } \\
(\%)\end{array}$} & \multirow{2}{*}{$\begin{array}{l}\text { Bulk } \\
\text { density } \\
\left(\mathrm{g} / \mathrm{cm}^{3}\right)\end{array}$} & \multicolumn{2}{|c|}{$\begin{array}{lll}\begin{array}{l}\text { Mass basis } \\
\text { content }(\mathrm{g} / \mathrm{g})\end{array} & \text { water } \\
\end{array}$} \\
\hline & Clay & Silt & Sand & & & FC & PWP \\
\hline $0-20$ & 6.70 & 1.90 & 91.40 & 0.87 & 1.65 & 0.080 & 0.045 \\
\hline $20-40$ & 4.80 & 4.10 & 91.10 & 0.82 & 1.57 & 0.095 & 0.049 \\
\hline $40-60$ & 7.75 & 19.75 & 72.50 & 0.81 & 1.46 & 0.122 & 0.073 \\
\hline $60-80$ & 7.20 & 19.70 & 73.10 & 0.69 & 1.61 & 0.131 & 0.077 \\
\hline $80-100$ & 7.42 & 17.94 & 74.64 & 0.67 & 1.58 & 0.146 & 0.092 \\
\hline & 6.774 & 12.678 & 80.548 & 0.77 & 1.57 & 0.115 & 0.067 \\
\hline
\end{tabular}

to restore $100 \%$ of ETc $(\mathrm{FI})$, considered as full irrigation. The deficit irrigation treatment consists on recovering $70 \%$ of the ETc (DI70) for potato, pepper, carrot and faba bean. While for barley crop, three irrigation treatments were used; full irrigation treatment $(\mathrm{FI})$, continuous deficit irrigation (DI50), regulated deficit irrigation during both development tillering and maturity stages (DI-TM). The SWB treatment were compared to farmer practices which consist in applying fixed irrigation amount once every 4 to 6 days for all the crops.

The crop water requirement was calculated using the water balance method by means of a spreadsheet program developed for Excel in order to estimate the irrigation timing and amount based on cumulative soil water depletion. The crop evapotranspiration (ETc) was estimated for a daily time step by using ETo combined with a crop coefficient. ETo was estimated by means of FAO-56 Penman-Monteith method as given in Allen et al. (1998). The Kc was computed following the dual crop coefficient approach that provides for separate calculations for transpiration and evaporation from soil.

Two Barley (Hordeum vulgare L.) provenances; local from the region of Medenine and Kerkeni from the region of Kerkena were sown on 4 and 20 December, respectively, in 2013-2014 and 2014-2015 in $70 \mathrm{~cm}$ rows space and with sowing density about $80 \mathrm{~kg} / \mathrm{ha}$. Barley was harvested in the fourth week of May.

Potato was planted on 9 September in 20122013 and 2013-2014 and irrigated based on three treatments. Every year, potato was harvested in the first week of January.

Carrot was planted on 14 October in 20122013 and 2013-2014 and the same irrigation strategies based on soil water balance method (FI and DI70) were adopted and compared with farmer method (FM). Carrot was harvested in the fourth week of February. Two faba bean varieties (Luz di otono and local) were sown on 17 October in 2012-2013 and 2013-2014

The same irrigation strategies (FI, DI70 and Farmer method) applied for the previous crops were used. During the second season, $92 \mathrm{~mm}$ of rains were received and resulted in the improvement of the crop yield compared to the first one which was characterized by the absence of rainfall.

Pepper was transplanted in the first week of May in both seasons (2012-2013 and 20132014) and irrigated based on the soil water balance technique (FI and DI70) and the farmer method. The variety Baklouti, widely used in the region because of its high paprika production, was planted with a density of 60.000 plant/ha. The first harvest was considered for fresh green pepper yield and the three other picking were performed for paprika production.

The deficit irrigation treatment consists on recovering $70 \%$ of the ETc (DI70) for potato, pepper, carrot and faba bean. While for barley crop, three irrigation treatments

were used; full irrigation treatment $(\mathrm{FI})$, continuous deficit irrigation (DI50), regulated deficit irrigation during both development tillering and maturity stages (DI-TM). The SWB treatment were 
compared to farmer practices which consist in applying fixed irrigation amount once every 4 to 6 days for all the crops. The crop water requirement was calculated using the water balance method by means of a spreadsheet program developed for Excel in order to estimate the irrigation timing and amount based on cumulative soil water depletion. The crop evapotranspiration (ETc) was estimated for a daily time step by using ETo combined with a crop coefficient. ETo was estimated by means of FAO-56 Penman-Monteith method as given in Allen et al. (1998).

The Kc was computed following the dual crop coefficient approach that provides for separate calculations for transpiration and evaporation from soil.

Two Barley (Hordeum vulgare L.) provenances; local from the region of Medenine and Kerkeni from the region of Kerkena were sown on 4 and 20 December, respectively, in 2013-2014 and 2014-2015 in $70 \mathrm{~cm}$ rows space and with sowing density about $80 \mathrm{~kg} / \mathrm{ha}$. Barley was harvested in the fourth week of May.

Potato was planted on 9 September in 20122013 and 2013-2014 and irrigated based on three treatments. Every year, potato was harvested in the first week of January.

Carrot was planted on 14 October in 20122013 and 2013-2014 and the same irrigation strategies based on soil water balance method (FI and DI70) were adopted and compared with farmer method (FM). Carrot was harvested in the fourth week of February.

Two faba bean varieties (Luz di otono and local) were sown on 17 October in 20122013 and 2013-2014. The same irrigation strategies (FI, DI70 and Farmer method) applied for the previous crops were used. During the second season, $92 \mathrm{~mm}$ of rains were received and resulted in the improvement of the crop yield compared to the first one which was characterized by the absence of rainfall.
Pepper was transplanted in the first week of May in both seasons (2012-2013 and 20132014) and irrigated based on the soil water balance technique (FI and DI70) and the farmer method. The variety Baklouti, widely used in the region because of its high paprika production, was planted with a density of 60.000 plant/ha. The first harvest was considered for fresh green pepper yield and the three other picking were performed for paprika production.

\subsection{Statistical analysis}

Analysis of variance was performed to evaluate effects of irrigation treatments on crops (barley, potato, carrot, fava bean and pepper) yield, WP and soil salinity using the Statgraphics (www.statgraphics.com). The LSD test at 5\% level was used, to evaluate the difference between treatment means.

\section{RESULTS AND DISCUSSION}

Five factors were analyzed to assess the response of considered crops to water supply and their importance at the farm level: crop yield, water productivity, soil salinization and economic return.

\subsection{Soil salinity}

In the absence of rainfall, the higher salinity values were observed under vegetables crops (carrot, potato and faba bean and pepper). While, the rainfall received in the second season contributed to salt leaching and the soil salinity values at harvest for most of the crops remain lower than $4 \mathrm{dS} / \mathrm{m}$.

The soil salinity values measured at the end of barley growing season were slightly higher than $4 \mathrm{dS} / \mathrm{m}$ even with the important amount of rainfall received during both season (2013-2014 and 2014-2015) and that may be due to the fact that barley harvest coincide with the period of high evaporative demand. 


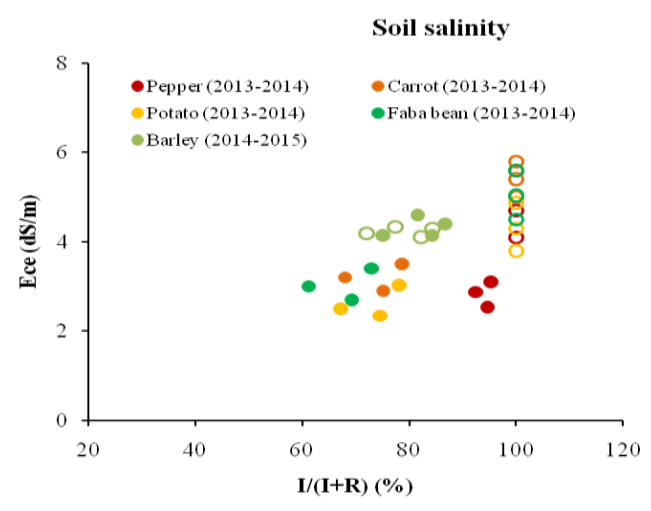

Figure 2. The soil ECe at the end of season for the five crops according to the percentage of irrigation water per the total applied water, filled symbols (second season) and open symbols (first season).

The full irrigation strategy maintains relatively low soil salinity compared to the deficit irrigation strategy and farmer method. The highest amount of water applied under FM resulted also in salt accumulation in the root zone. In fact, the impact of irrigation strategies on the soil salinization at the harvest is presented in figure 2 and the ECe values observed under FM are significantly higher, as indicated the LSD test at $5 \%$ in table 2 , for both seasons compared to the other strategies. While, for all irrigation strategies

$(\mathrm{I} / \mathrm{I}+\mathrm{R})$ the final soil salinity remains lower than irrigation water salinity $(\mathrm{ECi}=6$ $\mathrm{dS} / \mathrm{m})$. The maintaining of low soil salinity, despite the important amount of salts added by irrigation, was attributed to the amount of rainfall received during both seasons.

\subsection{Crops yield}

The difference in yield is related to the difference in marketable yield produced: fresh yield (potato, faba bean and carrot) or dry yield (barley and pepper). The higher yields were obtained with carrot, potato and faba bean, while carrot used more water compared to potato and Faba bean (Figure 3). Barley and pepper consumed more water due to their longer cycle.

For barley, the yield produced in the season 2013-2014 was higher than those recorded in 2014-2015. This difference can be attributed to the difference in amount of total rainfall received and its distribution. The reduction of water supply below the $400 \mathrm{~mm}$ caused a significant reduction in yield compared to the optimal water supply (FI) as presented in table 2. Providing more water around 600 $\mathrm{mm}$ under farmer method resulted also in yield reduction especially the grain yield.

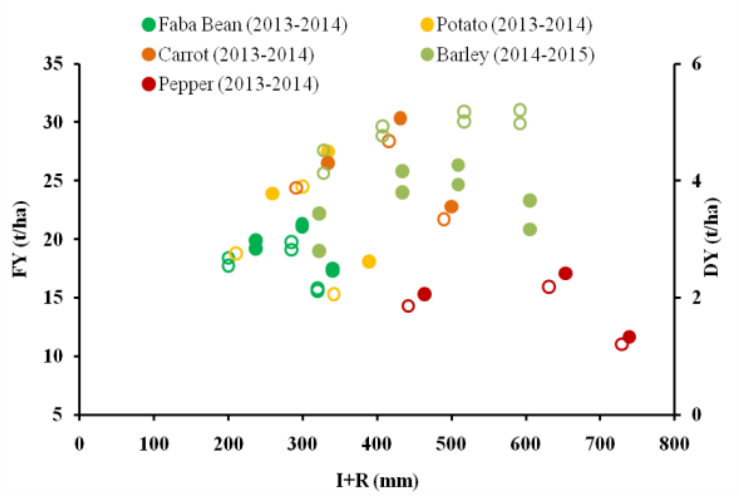

Figure 3. Yield for the five crops (potato, barley, carrot, faba bean and pepper) under different water supplies (irrigation and rainfall) for both seasons, filled symbols (second season) and open symbols (first season).

Thus, the increasing in water supply cannot result usually in yield increase. In fact, farmer irrigation practice seemed to be not adapted to the changes in crop needs during the growing season. The higher yield ranged between 4.8 and $5.2 \mathrm{t} / \mathrm{ha}$ was obtained for applied water amounts between 400 to 500 $\mathrm{mm}$.

For the vegetables (potato, faba bean, carrot and pepper), the higher yield was obtained in the second season due to the higher total water supplied (Figure 3). However, for both seasons, the higher yield was produced under the full irrigation strategy. In fact, with 300 to $330 \mathrm{~mm}$ yield was ranging between 24 to $27 \mathrm{t} / \mathrm{ha}, 600$ and $650 \mathrm{~mm}$ of water consumed resulted in 2.2 to $2.4 \mathrm{t} / \mathrm{ha}, 400$ and $420 \mathrm{~mm}$ produced 28 to $30 \mathrm{t} / \mathrm{ha}$ and $19-21$ t/ha was produced under 250 to $300 \mathrm{~mm}$, respectively for potato, pepper, carrot and faba bean.

The reduction of $30 \%$ of optimal water supply resulted in small yield reduction for 
carrot, pepper and faba bean, while it caused a significant yield reduction for potato especially in the absence of rainfall. Thus, we could note the sensitivity of potato to water restriction.

However, the increase of water supplied observed under the farmer method, ranging between 50 to $100 \mathrm{~mm}$ depending to the crop, resulted in significant yield reduction for most of the crops. Therefore, this reduction can be attributed to the higher values of soil salinity observed under this method. The continuous use of farmer practices during dry seasons may induce the soil degradation at long term.

\subsection{Total water productivity}

The TWP increase with the decrease of the water amounts supplied, the highest values were obtained under the deficit treatment DI-50 for barley and DI-70 for carrot, potato, faba bean and pepper (Figure 4).

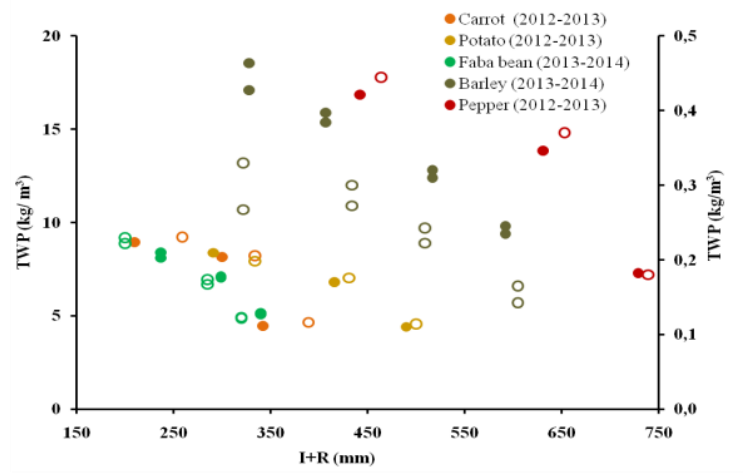

Figure 4: Total water productivity (TWP) for the studied crops under different water supplies (irrigation and rainfall) for both seasons, filled symbols (second season) and open symbols (first season).

For barley the higher TWP values were observed in the first season (2013-2014) due to higher yield produced under this season. While for the vegetables the values were comparable for both seasons. Therefore, the farmer method reduces the water productivity and the lowest total water productivity was obtained with FM for most of the crops

\subsection{Farmer Net return}

The higher net return was obtained with full irrigation treatment ranging between 1-1.7, 8-10.6, 6-8, 8.7-11.5, 4-6 thousand TND/ha, respectively for barley, potato, carrot, pepper and faba bean (Figure 5). For barley, a small reduction about $25 \%$ during tillering and maturity stages had a beneficial effect on farmer return. However, a reduction of $30 \%$ under the vegetable crops didn't improve the farmer income. The farmer method resulted in considerable reduction in the farmer gain for most of the crops due to the yield reduction and the surplus of water consumed compared to the soil water balance strategies.

During the second season, a decrease in net income was observed, even with less irrigation water used, as a consequence of market price decrease. In fact, the farmer return is depending to the abundance of such crop in the market and the number of farmers who plant this crop in the region.

Thus, Pepper is the highest remunerative crop despite its high water use followed by potato, carrot and faba bean. Barley provides the lower net return moreover the important water used. While, this crop is the most convenient cereal crop in the region and is mainly used for human food and animal feed supply. In addition, this crop didn't present problems of commercialization, labor, disease and pest.

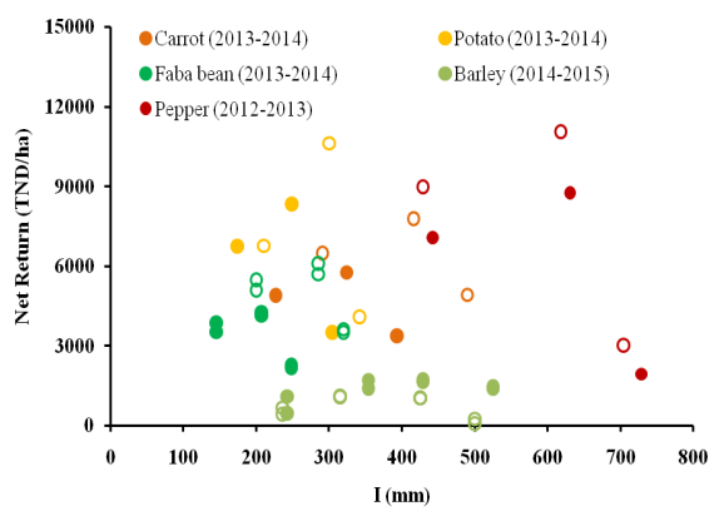

Figure 5. Economic net return for the five cultivated crops under different irrigation water supplies, filled symbols (second season) and open symbols (first season). 
Table 2. LSD Test at 5\% values ( evaluate difference between treatment means)

\begin{tabular}{|c|c|c|c|c|c|c|}
\hline & \multicolumn{2}{|c|}{$\begin{array}{c}\mathrm{ECe}(\mathrm{dS} / \mathrm{m}) \text { at } \\
\text { harvest }\end{array}$} & \multicolumn{2}{|c|}{ Yield (t/ha) } & \multicolumn{2}{|c|}{ TWP $\left(\mathrm{kg} / \mathrm{m}^{3}\right)$} \\
\hline & $\begin{array}{c}1^{\text {st }} \\
\text { season }\end{array}$ & $\begin{array}{c}2^{\text {sd }} \\
\text { season }\end{array}$ & $1^{\text {st }}$ season & $2^{\text {sd }}$ season & $1^{\text {st }}$ season & $2^{\text {sd }}$ season \\
\hline Carrot & 0.359 & 0.297 & 3.627 & 2.138 & 1.578 & 2.077 \\
\hline $\begin{array}{l}\text { Faba } \\
\text { bean }\end{array}$ & 0.466 & 0.384 & $4.698 / 4.749$ & $3.805 / 3.135$ & $2.002 / 2.037$ & $2.114 / 1.997$ \\
\hline Potato & 0.660 & 0.406 & 3.224 & 1.768 & 1.797 & 1.277 \\
\hline Pepper & 0.511 & 0.311 & 1.929 & 1.777 & 0.322 & 0.441 \\
\hline barley & 0.541 & 0.677 & $1.184 / 1.414$ & $0.546 / 0.403$ & $5.805 / 5.727$ & $2.144 / 2.919$ \\
\hline
\end{tabular}

Results show that planting pepper can improve the farmer income while farmers prefer crops which had a short cycle to ensure continuous return and pepper occupies soil for a long period in addition to its high labor needs. Therefore, crops that have a short cycle and coincide with rainfall season (autumn) should be cultivated alternating to avoid the drop of prices. Potato can provide a considerable return for farmer but it is more sensitive to disease and pest in addition to the commercialization problems for the poor and young farmers. Thus, farmer shouldn't be cultivated potato in the same plot successively. In fact, it can be cultivated in rotation with faba bean which allows good fixture of nitrogen in soil and less sensitive to water stress as presented previously (Figure 3).

Henrik et al. (2011) reported that including faba bean in the cropping system will have an economic benefit through the saving of $\mathrm{N}$ and the reducing of disease and weeds. Faba bean doesn't presents problems in the commercialization because this crop can be conserved after the fruit maturity and then sale the dry products with higher price. Pepper designed for paprika production (cv. Baklouti) can be a good alternative after short duration crops due to its high economic value. In fact, the long occupation of the soil and the high consumption of water can be more efficient if the farmer combines pepper with other crops (cucumber, water melon and melon) as mixed crops to increase his return in term of amount and time.

Barley can be cultivated just on a small plot to secure the family and the animal needs. The use of drip irrigation method and the irrigation scheduling are indispensable to improve the potential of production especially for barley where yield per hectare passed from $2 \mathrm{t} / \mathrm{ha}$ using surface irrigation (Nagaz et al., 1998, 2003) to $5 \mathrm{t} / \mathrm{ha}$.

\section{CONCLUSIONS}

The small scale irrigated areas, situated around shallow wells having high salinity ( $>4 \mathrm{dS} / \mathrm{m}$ ), present the main sources of income for an important number of farmers in the region. Olive trees, vegetables and barley are the main cultivated crops in these farms. These small scales supply most of the local markets. Thus, the improvement of farmer's livelihood is related to the sustainability and the enhancement of these small crop systems. The irrigation scheduling is the key to improve the crop water productivity and to reduce the environmental impact of saline water. The results showed the importance of this technique in the increase of yield compared to the farmer practice. The deficit irrigation with small reduction $30 \%$ can be useful strategy with low yield reduction in the case of barley and faba bean crops. The choice of the crop as well as the crop management is key factors to improve farmers' income and ensure its continuation. The short cycle's crops such as potato; carrot and faba bean benefited more from rainfall events where the impact on soil salinization is low especially in wet season. In addition, these crops provide reasonable return for farmers. The sensitivity of potato can be avoided through a better crop rotation. High remunerative crop such as paprika is interesting in the system. The possibility of mixing this crop with other crops such as cucumber, water melon and melon can be a 
good alternative that could be studied to identify the efficiency of this combination. The farmers consider barley as essential cereal for their nutrition and for animal feeds, although its presence in the system shouldn't be yearly and minimized in small plot to conserve water for cash crops.

\section{REFERENCES}

El Mokh, F. 2011. Adaptation of irrigation and crop management under water deficit conditions of southern Tunisia. Proceedings of the XIV IWRA World Water Congress on "Adaptive Water Management: Looking to the future", Enotel Resort, Porto de Galinhas PE Brazil, CD-rom, 25-29 September 2011.

Erkossa, T. 2009. Impacts of Improving Water Management of Smallholder Agriculture in the Upper Blue Nile Basin CP 19 Project Workshop Proceedings agronomy journal.

Henrik H., Mark P., Erik, J. 2011. Faba bean in cropping systems, the magazine of the European association for grain legume research Issue No.56 April 2011.

Horst, M.G., Shamutalov, Sh.S., Pereira, L.S., Gonc,alves, J.M. (2005). Field assessment of the water saving potential with furrow irrigation in Fergana, Aral Sea Basin. Agric. Water Manage. 77, 210-231.

Nagaz K., Ben Mechlia N. 1998. Barley production under different irrigation regimes with two water qualities. Agricoltura Mediterranea, Vol. 128(1), 28-33.

Nagaz, K., Ben Mechlia, N. 2003. Etude de la consommation en eau et de la production de l'orge sous irrigation à l'eau salée. Revue des Régions Arides 14 (1): 17-29.

Tanner, CB. And Sinclair, TR. 1983. Efficient water use in crop production: research or re-Search. ASA, CSSA, SSSA: Madison, Wisc. (USA); 1-27.

Webber, A. H. 2008. Improving irrigated agriculture in the Fergana valley, Uzbekistan, Department of Bioresource
Engineering McGill University, Montreal Submitted March 2008. 